http://dx.doi.org/10.18778/8088-266-9.08

Ewa Ciszewska*

\title{
Socialist film co-productions The case of the Polish-Czechoslovak film co-production What Will My Wife Say to This? (1958) by Jaroslav Mach
}

It is an established fact that co-productions were part of the post-war landscape of film architecture in socialist states. The function and consequences of co-productions made in the Eastern Bloc were considerably different from those made in Hollywood or Western Europe, owing to the idiosyncratic conditions of the Central European national film making industries: they were indeed nationalised and as such politically subordinated to the centre of power in Moscow. The film-making Europe of the 1920s sought to face the challenge of the global Hollywood primarily by means of distribution contracts and quotas, whereas co-productions played a minor role in this endeavour ${ }^{1}$. The socalled international productions were one way of grappling with American competitors; at this particular instance it is worthwhile to note at least these three institutions: the Swedish Svensk Filmindustri, the German Westi, and the Viennese production studio Sascha Film. The selection of topics and the international cast resulted in the production of 'continental' films, which were supposed to epitomise the cosmopolitan character of Europe and remain unattached to any specific nationality ${ }^{2}$. After WWII, the co-productions made by France and Italy were aimed at giving a competitive edge to European films and thus broadening their impact on the market. To quote but one example, more than a half of the film productions in France in 1957 involved a co-producer from abroad (63 films out of 127$)^{3}$.

Soon after the war ended, most of the Eastern Bloc countries signed bilateral contracts with their socialist neighbours delineating the shape of their cultural co-operation. Despite their fairly general character, these documents

* University of Łódź.

${ }^{1}$ K. Thompson, Narodziny i schyłek filmowej Europy, transl. T. Kłys, [in:] Kino Europy, ed. P. Sitarski, Rabid, Kraków 2001, p. 31.

2 A. Kołodziejczyk, Wspótpraca międzynarodowa $w$ dziedzinie kinematografii, PWSFTviT im. L. Schillera w Łodzi, Łódź 2004, p. 51.

${ }^{3}$ A. Jäckel, Dual Nationality Film Productions in Europe after 1945, "Historical Journal of Film, Radio and Television” 23, vol. 3, p. 231-243 quoted from: P. Skopal, „Svoboda pod dohledem“. Zahájení koprodukčního modelu výroby v kinematografiích socialistických zemí na př́kladu Barrandova (1954-1960), [in:] Naplánovaná kinematografie. Český filmový průmysl 1945 až 1960 , ed. P. Skopal, Academia, Praha 2012, p. 103. 
mentioned international co-operation in film making, while more detailed declarations stipulated that co-producing was supposed to be one of the elements aimed at strengthening mutual relations. These co-productions were to be a manifest sign of brotherhood, a testimony to the close relations between the countries involved. It might have seemed that these circumstances were more than sufficient to make a co-production possible, not least because of the political situation which was favourable for such undertakings as it guaranteed the viability of film budgets (provided that the films were bound for distribution).

These plans, however, were being stalled by the policy of the USSR until about 1956. The policymakers from Russia looked suspiciously on the attempts at co-operation between socialist and capitalist countries (which is self-explanatory), but - what must have come as a surprise - voiced their disapproval of the planned common initiatives of the Eastern Bloc, which, they argued, resulted from their concern for the ideological quality of these projects $^{4}$. The policy of cultural isolation, pursued in Soviet Russia since 1948, had an impact on the situation in the whole of Central Europe, not to mention the USSR itself, where the ambitious plans of Mosfilm were quashed: the minister of cinema production Ivan Bolshakov and his deputy Mikhail Kalatozov planned that the Moscow studio should take the leading position in the European cinema and produce 80-100 films per year, partly owing to co-productions, both with socialist and capitalist states. ${ }^{5}$ As a result of the hard-line policy and lack of support from the Soviet authorities, the documents concerning the co-operation in film production between the Eastern Bloc countries could be implemented only in the late 1950s, which was because of the fact that by that time the bureaucratic system had become more liberal and less strict in hampering contacts with the West.

The brief discussion above clearly indicates that the independence and self-reliance of the national cinema markets in Central Europe was illusory, since they heavily depended on the course of policy established by Moscow. For this reason the observation of Pavel Skopal seems well-founded, namely that the film culture of the Eastern Bloc was a global system within which parallel phenomena were taking place in the national cinema industries. ${ }^{6}$

\section{Co-production as a process of negotiating meanings}

Every co-production results from a process of negotiating conflicting interests which reveals cultural tensions and stereotypes. A particularly telling example of this phenomenon is the Polish-Czechoslovak co-production What Will My Wife Say to This? by Jaroslav Mach (1958; Polish title: Zadzwońcie do mojej żony, in Czech: Co rekne žena). The history of its making and reception

\footnotetext{
${ }^{4}$ P. Skopal, op. cit., p. 109-110.

5 Ibidem, p. 109.

${ }^{6}$ Ibidem, p. 105.
} 
can be reconstructed and analysed on the basis of archival material which provides an insight into the entire production process, beginning with the approval of the idea, the changes introduced in the subsequent versions of the script, and the circumstances of the actual film making, and, finally, the reception of the film in Poland, Czechoslovakia and other countries. Following this observation, I will concentrate in this article not only on the film in its final shape, but also on all of its potential versions. I am firmly convinced that this particular case study of Polish-Czechoslovak co-operation will illustrate that it is both justified and advisable to adopt a transnational perspective on the history of Polish and Czech cinema and that a parallel reading of archival material offers a number of advantages.

The film What Will My Wife Say to This? is important on several accounts. First of all, it was historically the first Polish-Czechoslovak co-production after WWII and the second after the 1933 film Twelve chairs by Michał Waszyński and Mac Frič. Secondly, both countries were involved in the production at all stages of the process. The fact that it was their first post-war co-production was a guarantee of receiving a considerable budget and all the other privileges assigned to 'priority' productions, which on the other hand obliged the film makers to adopt the 'correct perspective' and get across an appropriate ideological message. We have to admit at the very outset that this film left much to be desired from the artistic point of view, but it is nevertheless worthy of attention because of the fact that it illustrated Polish-Czechoslovak relations by referring to an image of a loving relationship, so characteristic of the socialist co-productions from that period ${ }^{7}$. Considering the prestigious character of this co-production, the image of both nations and their mutual relations presented in the film may be seen not only as a comprehensive illustration of the contemporary knowledge and stereotypes concerning the neighbouring countries, but also as a manifest sign of the official cultural policy ${ }^{8}$.

\section{Polish-Czechoslovak co-operation in 1945-1957}

It may seem surprising that it took over a decade from the Polish-Czechoslovak agreement of the year $1947^{9}$ before the first post-war production actually took place, in spite of the fact that the first co-production of a feature film

7 Skopal notes that this motif appeared in six out of eight co-production films made in Barrandov before 1960; ibidem, p. 112

${ }^{8}$ It received a 'B' category in Czechoslovakia, which means that it was regarded as a film of exemplary ideological value. Distribuční list 119/58, 21 července 1958, file no. 703, Narodní filmový archiv.

9 See Deklaracja Czechostowackiego Towarzystwa Filmowego i Przedsiębiorstwa Państwowego "Film Polski" o wspótpracy polsko-czechosłowackiej w dziedzinie kinematografii, 8 November 1947, Warszawa, [in:] Dokumenty i materiaty do historii stosunków polsko-czechosłowackich, vol. I, 1944-1960, part I, 1944-1948, ed. W. Balcerak, Polska Akademia Nauk i Czechosłowacka Akademia Nauk, Zakład Narodowy im. Ossolińskich, Wydawnictwo Polskiej Akademii Nauk, Wrocław-Warszawa-Kraków-Gdańsk-Łódź, 1985, p. 295-296. 
was scheduled for $1948^{10}$. Having said that, it does not mean that during those ten years nothing happened in the cultural relations between Poland and Czechoslovakia. In that period cultural contacts took the shape of a residency programme for writers, visits of musical groups and theatre performances, and the publishing of translated literary works. All these activities were official in character and the cultural figures who could benefit from the opportunity to travel abroad had to subscribe to the policies of the ruling party ${ }^{11}$.

The Polish-Czechoslovak co-operation thrived despite the fact that as yet not a single film had been produced in co-production after the war. The Polish film industry practically disappeared in the wake of the war; film people were dispersed and most of the educational and organisational initiatives planned before the war could not come to fruition. In the rebirth of Polish cinema it was indeed a salutary opportunity for Polish film makers that there appeared an opportunity to co-operate with film colleagues from abroad, a circumstance which helped in the process of rebuilding the institutional and personal structures of the cinema industry in the country. The Polish-Czechoslovak relations in the very first years after the war were clearly lop-sided, with Czechoslovakia being clearly the giver and Poland the recipient. These uneven proportions can be observed in the programme of common activities in the field of cinema planned for the year 1948, where Czechoslovakia was obliged to offer support to Poland, not least in the form of scholarships to be funded by the Czechoslovak Film for Polish film students and practitioners, running film training for a group of Polish colleagues in Zlín at the film summer school, and reserving a few subsidised places for Polish students in the Faculty of Film at the Academy of Arts in Prague. Polish Film (Film Polski) was not obliged to carry out any particular actions ${ }^{12}$.

It is beyond all doubt that the most characteristic example of the post-war Polish-Czechoslovak co-operation was the joint effort of the Polish director Aleksander Ford and the Czech cameraman Jaroslav Tuzar in making these three films: Ulica Graniczna (Border Street, 1949), Młodość Chopina (Chopin's Young Age, 1952) i Piatka z ulicy Barskiej (The Five Boys of Barska Street, $1954)^{13}$. In addition to that, the Czech director Bořivoj Zeman made in Poland

10 See Plan pracy Komisji Mieszanej Polsko-Czechosłowackiej do realizacji umowy o wspótpracy kulturalnej między Rzeczpospolita Polskq a Republika Czechostowacka na rok 1948, 9 February 1948, Warszawa, [in:] Dokumenty i materiaty do historii stosunków polsko-czechostowackich..., p. 334 .

${ }^{11}$ For more on this topic see A. Szczepańska, Warszawa-Praga 1948-1968. Od nakazanej przyjaźni do kryzysu, Wydawnictwo Naukowe Uniwersytetu Szczecińskiego, Szczecin 2011, p. 200-246; for literary contacts see D. Bielec, Sprawy czeskie w polskich drukach drugiego obiegu, Wydawnictwo Uniwersytetu Jagiellońskiego, Kraków 2008, p. 15-29.

12 Plan pracy Komisji Mieszanej Polsko-Czechosłowackiej..., p. 334.

${ }^{13}$ For details about this co-operation see: P. Bergmannová, Vzájemné česko-polské vztahy v oblasti filmu po 2. světové válce (... a pruní česko-polský film Hraniční ulička/Ulica graniczna), [in:] Rozumíme si navzájem? Možnosti reflexe minulosti v současnosti v české a polské literatuře, jazyce a kultuře 20. Století, ed. L. Martinek, Slezská univerzita v Opavě, Opava-Opole 2011, p. 131-140 and P. Bergmannová, Poválečné česko-polské filmové kontakty v letech 1945-1949 do 
the film Powrót (The Return; or, alternatively: Ślepy tor; Cul-de-sac, 1948) based on an idea of Tadeusz Kański. It is also worth noting the unrealised plan for the feature film Jeden więcej (One more; or, alternatively: Autobus; The Bus), based on the idea of Jan Kadár and Bořivoj Zeman. The plot of the film, drafted by Kadár and Vratislav Blažek, followed the production pattern whose main theme was the hunt for a saboteur who fomented conflicts between Polish and Czech bus mechanics. The introduction to the script begin with the following statements: We decide to choose contemporary topics as opposed to historical (the latter are always riddled with pathos). It is decidedly on purpose that we avoid topics from the recent past (the pre-war years), which in a similar way to the period of occupation are devoid of the slightest touch of humour, a humour that we need to build a friendly atmosphere of mutual trust and kind-heartedness ${ }^{14}$. The draft for the script authored by Stanislaw Dygat did include this indispensable 'touch of humour', but remained within the schematic constraints imposed by the framework designed by Kadár and Zeman. It is perhaps fortunate that this initiative foundered and ended with just two drafts for the script and a résumé, which are held in the collections of the Filmoteka Narodowa (National Film Archive) in Warsaw.

The Polish-Czechoslovak co-operation in the 1950s was not as lively and intense as it had been straight after the war. The Polish cinema industry was becoming increasingly self-reliant and the newly built halls of the Feature Film Studio in Łódź made it possible to produce films without the need to use the services of the Prague Barrandov Studio, where the above mentioned films by Ford were produced. At the same time one can observe the increasingly formal nature of mutual relations and the emphasis on fulfilling the officially accepted plans. One of these was launching a co-production initiative, i.e. producing a film involving both partners with regard to its artistic shape and financial backing (Ford's films with Tuzar, who participated in the venture as the cameraman, were in fact Polish productions). This initiative could be launched only in the late 1950s, when it took the form of the film by Jaroslav Mach titled What Will My Wife Say to This?

\section{The fortunes of the script examined by the Script Evaluation Committee}

The script for the film What Will My Wife Say to This? was on the agenda of the meeting of the Script Evaluation Committee held on 26 April 1957 and presided over by the chairman Leonard Borkowicz ${ }^{15}$. Apart from Borkowicz,

premiéry pruního česko-polského filmu Hraniční ulička, "Acta Universitatis Palackianae Olomucensis. Facultas Philosophica. Philosophica - Aesthetica”. Kontexty II. Literaria, Theatralia, Cinematographica 22 - 2000, ed. M. Sýkora, Univerzita Palackého, Olomouc 2000 (2001), p. 87-99.

${ }_{14}$ Jeden więcej, według pomysłu Jana Kadára i Bořivoja Zemana. Projekt scenariusza filmowego, 12 November 1948, Filmoteka Narodowa S-181, p. 1.

${ }_{15}$ Filmoteka Narodowa, A-214, poz.75. 
the Committee was composed of 17 members, listed alphabetically in the minutes, including writers and screenwriters (Jerzy Andrzejewski, Romant Bratny, Stanisław Dygat, Ludwik Starski, and Ścibor-Rylski), directors (Antoni Bohdziewicz, Jerzy Kawalerowicz, Jan Rybkowski, and Jerzy Zarzycki), representatives of the production division (Edward Zajiček) as well as the 'representatives of Czech cinema' (who were not mentioned by name, but certainly included Jaroslav Mach, the director of the film).

The discussion began with strident criticism, with Bohdziewicz arguing that the script was 'an illustration of pathological obsession with erotic innuendos', characterised by 'an unsavoury taste' and 'an anachronistic type of humour, obsolete and dry'. Other remarks criticised the characters, who were 'one-dimensional and identical' (Bohdziewicz), and demonstrated that there was 'a fair number of untruths concerning Poland and Czechoslovakia (Kawalerowicz). The criticism was bolstered by Andrzejewski, Bratny, Braun, and Toeplitz and it seemed that the case was decided and that the script would not be accepted for production. However, there were also the dissenting voices of the members who advocated a change of perspective and emphasised the ideological purport of the film instead of its artistic value. No one attempted to praise the script as all agreed that it would require substantial changes - but there appeared an argument emphasising the importance of launching the first post-war Polish-Czechoslovak co-production. The most vociferous advocates of this project were Ścibor-Rylski, Zarzycki, and Ludwik Starski. The latter went as far as to put forward the argument that the committee was not infallible and drew attention to the fact that it had enthusiastically embraced and supported ideas which resulted in poor quality films. Starski was the only one among the committee who referred to arguments in favour of this particular co-production which were not concerned with the public image or ideological content of the film. He reminded the members of the economic aspect, which indicated that the cost of the co-production to be covered by Poland was 'a mere 2.5 million zlotys'. In addition to that, Starski pointed out that 'the Czechs will be publicising this film for their audience', a perspective which undoubtedly increased the chances of the international success of the film.

The statements from the 'representatives of the Czech film industry' clearly demonstrate puzzlement at the hard-line approach of their Polish colleagues, which was followed by outright exasperation: the arguments about the effort which had been made towards bringing the project to that stage were soon coupled with others, such as the argument of authority ('the script was written by a well-known Czech satirist') or the suspicions of Polish resentment towards co-operation with the Czechs. They saw the critical remarks about this particular script as a sign of disapproval of the whole idea of coproductions. Confronted with such arguments, the committee had no other choice than to express their willingness to co-operate with their fellow film makers and accept the script on the proviso that it would be changed under the supervision of Ludwik Starski, who offered his 'disinterested co-operation 
in producing this film'. The corrections were made at a brisk pace, for the shooting began no later than in May 1957 and ended in February next year. The film premiered on 26 September 1958 in Czechoslovakia and on 20 December 1958 in Poland.

\section{The metamorphoses of the script}

The favourable argument concerning the quality of the text submitted to the Committee consisted of the view that 'the script had been reviewed a number of times and the authors had been working on this since last year'. Indeed, the surviving archival material includes several version of the text, preserved both in the Polish (the National Film Archive) and Czech archives (the Barrandov Studio Archive and the National Film Archive in Prague). ${ }^{16}$ Contrary to the view of the authors, who wished to present these versions as an indicator of the high quality of their work, the texts are testimony to the attempts at reconciling numerous interests, which were at times contradictory: on the one hand, there was an evident inclination of the text towards the bureaucratic comedy and 'communal satire' ${ }^{17}$, while on the other one could not miss the ambition to create a sort of romantic comedy where the actors who performed the roles of the two lovers represented the two countries - Barbara Połomska for Poland and Josef Bek for Czechoslovakia. There were thus two aspirations which collided in the script: the satirical and the representational; the task of the latter was to offer a favourable portrayal of the two 'lovers'.

Taking into account both the literary material and the film text, I shall analyse and interpret the changes introduced into the subsequent versions of the script. In doing so, I will use the actual film as the main point of reference and demonstrate places where the changes were substantial, without however ignoring others which were only slightly modified. I do not intend to provide a meticulous and comprehensive analysis of the introduced changes, but rather to emphasise the motifs and themes which constituted, as it were, 'trouble spots', characteristic for their moral, social or political aspects.

${ }^{16}$ I wish to express my gratitude to the Barrandov Film Studio for their help in preparing this article.

${ }_{17}$ The communal satire (komunální satira) was concentrated on various inconveniences which citizens had to face in their daily life: unsufficient supplies, loafing at work, inefficient administrative staff and bureaucracy. This was the dominant genre of humour in the magazine 'Dikobraz' ('The Porcupine'), whose editor-in-chief in 1954-1957 was Václav Jelínek, the author of the script for What Will My Wife Say to This? See the entry Dikobraz, [in:] J. Knapík, M. Franc et al., Průvodce kulturním děním a životním stylem v českých zemích 1958-1967. vol. I, Academia, Praha 2012, p. 250-252. 


\section{Why did Adam Mickiewicz prove to be a better lover that Władysław Jagiellończyk?}

Irena and Tůma, the protagonists of the film, engage in a flirtatious relationship, which leaves much room for a potential love affair. With this in mind, Irena promised his guest that during his visit to Cracow she would show him her first great love. She is married, but the fact that she had been previously in love with other men than her husband gives Tưma some grounds for hope, at least at the very beginning, that his advances may prove successful. This hope, however, was soon lost, as Tůma realised that there was little room for another man at Irena's side, given that she was in relationships with both her husband and the 'lover'.

The first version of the script takes the two characters to the Wawel, the burial place of Polish monarchs, where Irena wants to introduce her 'lover' to the guest. They enter the cathedral and stand in front of the tomb of Władysław Jagiellończyk, who turns out to be her young love. At every break I would run away from school, whenever I had a moment I would talk to him for hours on end... Such a patient lover... ${ }^{18}$. As she looks on the countenance of the king, the face of Tůma appears on it. At the same time Tůma comments in his inner monologue: She is so sweet... and so impractical... she lives in a people's democratic state and falls in love with a king.

This 'impracticality' of choosing a member of royalty as a lover led to a change in the later versions of the script: the king was replaced by Adam Mickiewicz - a poet, and, more to the point, a revolutionary. The fact that Jagiellończyk had ruled over Bohemia proved insignificant - his social background made him unfit for dating Irena, a socialist beauty. Unsurprisingly, the fragment where Tůma addressed his guide as 'Irena Jagiellońska' was similarly expurgated. The new lover, Adam Mickiewicz, whose statue towers over the Market Square in Cracow, was much better at meeting the criteria expected of socialist lovers - in addition to the Romantic and platonic character of the relationship, he evoked revolutionary connotations related to his participation in the Spring of Nations. There might have been another factor in changing the object of Irena's affection. Not long before the script was submitted to the committee, in 1955, Poland saw the grand celebrations of Mickiewicz's anniversary, an occasion which was a major challenge for the Polish authorities who tried to harness this event to serve their propaganda. That year saw also the publication of 'legitimate' anthologies and translations of his poems as well as two types of monographs devoted to his work: one addressed to the capitalist readership and the other for the people's democratic states ${ }^{19}$.

18 A literary script [Literární scénári]: Píseň o věrnosti, Václav Jelínek, Jaroslav Mach, October 1956, The Czechoslovak Film [Československý státní film], A Creative Group [Tvưrčí skupina] Bohumil Šmída - Vladmír Kabelík, 1977-56-mr, Národní filmový archiv, S-114-TS, p. 121.

19 A. Lisiecka, Działalność Komitetu Wspótpracy Kulturalnej z Zagranica w latach 19501956, [in:] M. Brodala, A. Lisiecka, T. Ruzikowski, Przebudować człowieka. Komunistyczne wysitki zmiany mentalności, ed. M. Kula, Wydawnictwo TRIO, Warszawa 2011, p. 254-255. 


\section{What a bureaucracy! Nothing of this sort would have happened in Poland! ${ }^{20}$}

The viewers of the film could have come to the conclusion that Poland and Czechoslovakia were entirely different as regards social and political life. Poland might have seemed like a Central European version of the West, with its light-hearted atmosphere reverberating with jazz and 'big-beat' music (a 'politically correct' term for rock music), and the freedom of travelling, unimpeded by any sort of bureaucratic nuisance. The troubles which Tůma had to cope with while in Prague (getting his passport stamped or buying a ticket) make one think of Czechoslovakia as a bureaucratic nightmare, particularly cumbersome for the average citizen. Interestingly, the earliest versions of the script are more caustic on the topic of bureaucracy and officialdom. Suffice it to quote three scenes located in Poland which did not make it to be included in the film.

The first of these takes place at a railway station in Łódź, where Irena fills in the forms necessary for sending on her luggage. Tưma carries on with his inner monologue: the official papers nag at me and remind me of my home country... For instance, I have not sent my personal questionnaire to the union, the opinion on Robert's book still rests on my desk... I have not filled in the form for social insurance... I have not returned the declaration that I will not take part in the survey concerning the preparations for harvest with the rapeseed combines ${ }^{21}$. One other scene has Tůma's guide, Rybińska, informing him that she will provide him with statistical data about developments in construction work in Poland. This prompts Tưma to comment: Papers, again! It seems that their forests grow thinner, just as they do back home ${ }^{22}$. Later on, after a tiring day which ended with a visit to the radio station, the man says: I spoke on the radio and hoped that no one would be interested, just as it is back home ${ }^{23}$.

Václav Jelínek, the author of the script, was well-known for his acerbic wit and uncompromising satire, which was aimed mainly at the absurdities of life under socialism. Even though the early 1950s in Czechoslovakia were characterised by relative tolerance for artistic freedom, Jelínek did not go unscathed after his plays were staged, where, as it seems, the humour went too far. The Czech historian Jiři Knapík argues that the criticism of bureaucracy expressed in Jelínek's play Skandál v obrazárně (The Scandal at the Gallery, 1953) gave a pretext for negative reviews of the performance ${ }^{24}$. Also his work

20 The exclamation of Tủma when confronted with the formalities at the Czechoslovak Foreign Office. The script for What Will My Wife Say to This?, Polish version, according to the script by Jelinek and Mach, edition[?]: Jan Fethke, dialogues: Zdzisław Skowroński; [no date], Filmoteka Narodowa, S-16541, D326/74, p. 4.

${ }^{21}$ The script for What Will My Wife Say to This?, Vaclav Jelinek, script: Vaclav Jelinek, Jaroslav Mach, Zdzisław Gozdawa, Wacław Stępień; ZAF "Iluzjon” Warszawa, Tvurci Skupina Smida-Kabelik, Praha 1957; Filmoteka Narodowa S-16541, D/94/78, p. 62.

22 Ibidem, p. 21.

${ }^{23}$ Ibidem, p. 26.

${ }^{24}$ J. Knapík, V zajetí moci. Kulturní politika, jeji systém a aktéři 1948-1956, Libri, Praha 2006, p. 237. 
as a satirist for "Dikobraz" became a source of trouble, while the magazine itself was subjected to the scrutiny of the Department of Propaganda in $1954^{25}$.

It seems that also in the case of $A$ song on fidelity, as the script was initially titled ${ }^{26}$, the conclusion was that the author took too much liberty while writing a text which contained so many mocking remarks and was so scathing with regard to social life under socialism. The fact that Jelínek had made these observations on his own while visiting Poland a few years earlier was considered irrelevant: (...) he could scarcely have missed some of the ridiculous practices of our dignified institutions established to foster international co-operation in culture and... research. Nor could he ignore some of our customs and various manifestations of the Old Polish hospitality which is still practiced today ${ }^{27}$. It turned out that criticism is acceptable, provided that it is administered in a reasonable amount.

\section{Polish-Czechoslovak brotherhood? Yes, but only to a reasonable extent}

One other scene has Irena say to Tưma: Look there, there is another proof of the companionship of our countries. According to the script, there was a young girl approaching, who was wearing colourful national dress (in the 'Eowicz' style) and riding a motorbike, a 'Jawa', which was a popular motorbike brand manufactured in Czechoslovakia. There follows a comment in the script, unattributed to any particular personage: Our people on your motorbikes ${ }^{28}$.

Both the literary material and the film itself contain a number of scenes intended to emphasise the affinities of the Poles and the Czechs, particularly with regard to knowledge about cuisine, alcohol varieties, tourist attractions, literature, and sport personalities of the other country. The overly friendly portrayal of Polish-Czechoslovak relations was toned down in the final version of the script so that the viewers could not interpret these scenes in a satirical sense, including the one mentioned above with the girl on a motorbike. The 'brotherly vignettes' were usually coupled with the inner monologues of Tůma, who commented bitterly on the ongoing events. In many instances over the course of work on the script the scenes as such were preserved, but were rid of those ironic comments. One should note for example the sentence with a comment from Ti̊ma who recalled a carousing evening spent with a Polish

${ }^{25}$ Ibidem, p. 245 .

${ }^{26}$ There is no direct indication of why the initial version of the title was abandoned. We may suspect that one argument in favour of changing the title was the earlier use of the phrase $A$ Song on Fidelity as the title of a poem celebrating the thirtieth anniversary of the Communist Party of Czechoslovakia (Píseñ o věrnosti. Baseň k 30. vyroči KSČ , Jindřich Hilč, 1951) and the title of the novel by Václav Řezáč (Píseñ o věrnosti a zradě, Václav Řezáč, 1956), which was published soon after the author's death.

${ }^{27}$ An advertisement leaflet in Polish, The National Filma Archive, Materiały CUF 703.

${ }^{28}$ The script for What Will My Wife Say to This?, p. 87. 
cloakroom attendant: And thus a brotherhood was established between the representatives of Polish and Czechoslovak peoples with regard to one of the important aspects of our lives ${ }^{29}$. In a similar vein, Tůma commented on the fact that he gave his hat as a gift to the attendant: and thus it had led to establishing a brotherly friendship between the representatives of the Polish and Czechoslovak peoples ${ }^{30}$. Neither of these comments appears in the film. These episodes purged of the ironic comments of Tưma lost their satirical, incisive and ironic overtones. They became 'genteel' manifestations of the Polish-Czechoslovak brotherhood.

Also the fragments on the duplicity of socialist culture were removed. This can be illustrated by another episode which was not included in the film: the main characters pay an unannounced visit to a cultural centre in Łódź. They see a group of musicians, who were playing jazz at that moment. Embarassed by the unexpected visitors, they immediately change musical instruments, pick up their folksy pipes and start playing Slavonic folk music. Tůma comments with a smile, saying: It is just as it is back home $e^{31}$. Later on in the same episode the characters look at a painting in the socialist realism style depicting tractors, combines, and men and women with rolled up sleeves. When Tưma asks the question whether the lady likes the painting, the answer is uncompromisingly negative. ${ }^{32}$

\section{Why is it that there are no ruins in Warsaw? Or that there are no factories in Kódź?}

The film was not, at least officially, a cogwheel in the mechanism of strengthening the tourism potential of Poland and Czechoslovakia by means of the common effort of the tourism and film industries. Neither of the two national tourist agencies - Orbis and Čedok - was involved as the commissioner of or a partner in producing the film, but undoubtedly the aim of this co-production was to encourage the citizens of Czechoslovakia to visit Poland. This intent did not escape the attention of many reviewers who referred to the favourable portrayal of both countries as an undeniably positive feature of the film - or, in fact, the only positive feature. As Krzysztof Teodor Toeplitz pointedly commented on the film:

We have made a film with no artistic advantages to either of the two involved parties - neither the Czech, nor us. It is to be hoped that at least Orbis could gain some advantage, for the only

${ }^{29}$ The literary script [Literární scénár]: Píseñ o věrnosti, p. 33-34.

${ }^{30}$ The script: Co řekne žena..., Václav Jelínek; The Literary Script [Literární scénář]: Václav Jelínek - Jaroslav Mach - Jan Fethke, Dialogues: Václav Jelínek - Zdislaw Skowroński, technical script: Jaroslav Mach, June 1957, Československý film Praha, The Creative Group [Tuůrči skupina] B. Šmída - V. Kabelík, Film Polski Zespół Autorów Filmowych 'Iluzjon', 1264-67, NFA, S-114-TS-2, p. 55.

31 The literary script [Literární scénár̆]: Píseň o věrnosti, p. 78-80.

32 Ibidem, p. 80. 
positive feature of this film is the fact that it gives a portrayal of some parts of Poland and Czechoslovakia as regards the opportunities for tourism. And if it had been Orbis or its Czech equivalent who stood behind the production of this film as their advertisement, I would not say a word. But given that it is shown to us as a result of artistic co-operation, I have to say that the film is, regrettably, a dud ${ }^{33}$.

Today, over fifty years after the premiere of the film, we may notice a striking similarity (obviously with certain limitations) between this production and such European films by Woody Allen as Vicky, Cristina, Barcelona (2008), or Midnight in Paris (2011), where an important part is played not only by the storyline, but also the scenery in which the action takes place. The aim of the film, in addition to making an emotional impact, is to publicise the charms of the portrayed places. Thus the film What Will My Wife Say to This? may be viewed in the perspective of 'film-induced tourism'. This particular notion involves enhancing the attractiveness of places long-established as potential tourist destinations; there seem to be two approaches to dealing with this: one is focused on the classic tourist sights (as it is in Allen's Midnight in Paris), while the other ventures to promote unusual tourist trails. A case in point for the latter approach is the film Samotári (Loners, 2000) by David Ondriček, where Prague is portrayed without the well-known sights of the Castle and the Charles Bridge. The film by Jaroslav Mach seems to have adopted both approaches, as it bolstered the tourist potential of the classic destinations such as Warsaw, Cracow, and Sopot and promoted new alternative ones such as Łódź.

I am going abroad! - Tůma shouts gleefully while leaving the Foreign Department in the Foreign Office of Czechoslovakia. His excitement must have been readily understood in Poland and Czechoslovakia, for it was not an easy task to get a travel permit, even for visiting other communist countries. In order to receive a visa, one had to follow procedures which could take several months, and to meet a number of requirements expected of all citizens wishing to travel abroad. No wonder then that Tưma is so happy; it also seems that he does not care so much about the destination - all that counts is that it involves crossing the border. Another scene, set on the stairs leading to the Foreign Office, is also intended to present Poland as an attractive destination: Tůma runs into a turban-clad man, clearly coming from the Middle East. The clash of these two elements, 'travelling to Poland' and 'an exotic character', leads to the obvious conclusion that visiting a neighbouring communist country may be an adventure just as exciting as travelling in the Middle East.

Also the selection of places to be visited by Ti̊ma serves the purpose of bolstering the image of Poland as an attractive tourist destination. The character will visit the following cities in that order: Warsaw, Łódź, Cracow, and Sopot. The image of Polish cities in the film by Mach is subject to the 'tourist glance' which ignores problematic places on account of their complicated history or the ideological aspect. The cities portrayed indicate selected positive features

${ }^{33}$ K. T. Toeplitz, Zadzwońcie do mojej żony, „Świat“ 1959, no. 5, no page number [the folder with clippings from Co řekně žena, NFA]. 
of Poland, taken with a stereotypical approach. Thus, Warsaw embodies modernity and progress, Łódź is a city of art and sport, Cracow is an epitome of tradition, and Sopot is shorthand for taking a rest in beautiful scenery.

Łódź is perhaps the most striking element in the series, given that even today it is only very rarely included in international travel guides. The characters of the film visit a painter's studio and a cultural centre. It may have been surprising to the Polish viewers that in What Will My Wife Say to This? the artistic traditions of Łódź are in the foreground as opposed to its industrial image. It was on account of its strong workers' movement that Łódź was known across Poland as the 'red' city, with its characteristic chimneys of cotton mills. But here, instead of factory halls, the characters visit artists' ateliers. We may suspect that the decision to disregard the workers' theme (even though there are some traces of it in the General Film Plan ${ }^{34}$ ) was intentional and aimed at avoiding episodes which might have evoked the motifs known from socialist realism. The film by Mach was supposed to become an example of socialist entertainment cinema, purged of all unnecessary didactic overtones (which in fact turned out to be unavoidable) and emphasising the joyful moments of life in a socialist country - the hard toil at the spinning machines was certainly not of this sort.

There might have been also practical reasons for placing Eódź on the list of places visited by Ti̊ma. After WWII the most important institutions related to film production were located in Łódź; hence the nickname of 'HollyŁódź' earned by a city of cotton mills. The Polish partner in producing the film was the 'Iluzjon' Film Authors' Team; the management of the process was assigned to the Feature Film Studio at 29 Łąkowa Street in Łódź. The atelier shots for What Will My Wife Say to This? were taken in the film set halls of this studio. It may be concluded that placing Eódź on the itinerary of the Czech tourist was a favourable circumstance for the budget and the management of this production.

The portrayal of Warsaw is no less problematic than that of Łódź. The images which appear in this portrayal include the modern residential district of Mariensztat, the imposing Palace of Culture and Science, the brand-new Tenth Anniversary Stadium, and the reconstructed Old Town Market Square. There is no indication whatsoever that WWII had ended a mere twelve years earlier and that at the moment of making this film Warsaw had its fair share of destroyed buildings - these are clearly noticeable in the documentary film Warsaw 1956 by Jerzy Bossak and Jarosław Brzozowski, who confronted the Warsaw of conspicuous social realist buildings and the gloomy pictures of ruins not far away from the city centre. By contrast, the film by Mach carries no hint that Warsaw was a city of ruins, either on the visual, or on the audial level. It is nevertheless significant that one version of the script included

${ }^{34}$ The background actors' payroll and list of episodes (Wykaz zatrudnienia statystów i epizodów) includes the entry Montá̇ łódzki 38a, which portrayed, among other places, the cotton mills. Plan generalny filmu Zadzwońcie do mojej żony / Co řekne žena..., Archiwum Państwowe w Łodzi [The National Archives in Łódź], nr akt 636. 
a scene where Rybińska and Tưma looked at the city from a terrace atop the Palace of Culture and Science; there the woman showed Tưma a postcard depicting Warsaw soon after the war. It was a picture of ruins, charred houses, and growing stacks of bricks. ${ }^{35}$

\section{Conclusions}

Film co-productions made in socialist countries betray numerous tensions resulting from the process of negotiating between the rules of entertainment cinema and the cinema subjected to ideological requirements. In the case of What Will My Wife Say to This? it is difficult to identify direct decisive impulses which led to eliminating or adding particular scenes to the script. This is perhaps true of all film productions. The introduced changes resulted from popular convictions about what was allowed or forbidden, what it was acceptable to show in the film and what should be avoided. In its subsequent versions, the script for What Will My Wife Say to This? was becoming more and more 'genteel' (the satirical elements were removed) and 'tourist-oriented' (Poland was portrayed as a country of modern architecture and luxury leisure resorts, without any references to the industrial landscape of Łódź or that of Warsaw shattered by war).

From today's perspective it is difficult to track and analyse the financial aspects of film co-productions from communist times in Poland, owing to the lack of material documenting the production process, and the fragmentary character of testimonials from the people involved. Edward Zajiček, the head of the production team for What Will My Wife Say to This?, noted that it was very common for co-productions to generate similar costs to a single-handed production for either of the involved parties, even though these costs were supposed to be shared between two or more partners. This situation resulted from the fact that co-productions involved a number of the so-called ineffective expenses, which cannot be detected in the final product, i.e. on screen. The costs rose because of the longer preparation time, larger personnel, travel and lodging expenses, sound engineering for the purposes of every partner involved, and a greater number of release prints, etc. ${ }^{36}$

The co-production was advantageous as it gave grounds for hope that the film would be distributed on a larger scale (at least in two countries). The film What Will My Wife Say to This? was distributed in the German Democratic Republic and Bulgaria (in addition to Poland and Czechoslovakia). The advertising materials were prepared also in English and Spanish, but there are no records of the distribution of the film in other countries than the four mentioned above.

35 Scenariusz literacki [Literární scénár]: Píseñ o věrnosti, p. 38.

${ }^{36}$ E. Zajiček, Poza ekranem. Kinematografia polska 1918-1991, Filmoteka Narodowa, Wydawnictwa Artystyczne i Filmowe, Warszawa 1992, p. 178. 
The popularity of the film must have been boosted by the fact that parts of the film were shot in attractive locations (it was hardly a coincidence that most photographs prepared for advertising in Czechoslovakia presented Poland's seaside) and that actors from abroad were involved in the production. The Czech viewers were familiar with both Barbara Połomska (who featured in the film Syrena Warszawska by Tadeusz Makarczyński which was shown at the festival in Karlovy Vary in 1956) and Hanna Bielicka, who performed in the play Z naši domoviny (From our own garden). in Prague in 1955 while on tour with the 'Syrena' Theatre. Władysław Szpilman gave a series of concerts for Czech audiences in 1956. Polish viewers knew both Josef Bek [1948: A Revolutionary Year (Revoluční rok 1848), Anna the Proletarian (Anna proletářka)], and the director Jaroslav Mach ${ }^{37}$ - at the time when the film What Will My Wife Say to This? was premiered, Polish cinemas showed the novel film Supernatural stories ( $O$ věcech nadprirozených), where one of the novels was directed by Mach. Five years later Polish cinema lovers could see the comedy Women keep their word (Slovo dělá ženu, 1953) produced under his direction.

When seen through the prism of culture and production, studying the co-productions made in the times of communist Poland reveals the transnational character of at least some Polish films. Such an approach makes it possible to read the history of Polish cinema as a field of competing trends and short-term interests.

\section{Summary}

This article offers an analysis of the Polish-Czechoslovak co-production What Will My Wife Say to This? (Co řekne žena, 1958, directed by Jaroslav Mach) as seen from the perspective of production-related and cultural factors. It provides a methodological background useful for the study of co-productions made in communist countries and presents the general circumstances of Polish-Czechoslovak co-operation in 1948-1958. The analysis of the film - the first Polish-Czechoslovak post-war co-production - shows the process of production as a field of conflicting goals and interests.

37 This might have been owing to a misunderstanding as the name of the director might have been confused with that of Jaroslav's elder brother, Josef Mach, who directed the film Nikt nic nie wie (Nobody knows anything) which won much acclaim in Poland. 